\title{
$\begin{array}{lllllllllllllllll}\mathbf{R} & \mathbf{O} & \mathrm{Z} & \mathbf{P} & \mathbf{R} & \mathbf{A} & \mathbf{W} & \mathbf{Y} & \text { I } & \text { A } & \mathbf{R} & \mathbf{T} & \mathbf{Y} & \mathrm{K} & \mathbf{U} & \mathbf{L} & \mathbf{Y}\end{array}$
}

Ks. Wojciech Góralski

Ius Matrimoniale

$31(2020) \mathrm{nr} 1$

DOI:10.21697/im.2020.31.1.01

Wydział Prawa Kanonicznego UKSW

\section{Przyczyna dalsza wykluczenia nierozerwalności małżeństwa w świetle współczesnego orzecznictwa Roty Rzymskiej}

(2000-2012)

Treść: Wstęp. 1. Mentalność prorozwodowa. 2. Brak formacji religijnej. 3. Osobowość kontrahenta. Zakończenie

\section{Wstęp}

Nierozerwalność małżeństwa, wynikająca z natury tego związku, zakorzeniona w osobowym i całkowitym obdarowaniu się małżonków, swoje ostateczne uzasadnienie znajduje „w zamyśle Bożym wyrażonym w Objawieniu: Bóg chce nierozerwalności małżeństwa i daje ją jako owoc, jako znak i wymóg miłości absolutnie wiernej, którą On darzy człowieka i którą Chrystus Pan żywi dla swego Kościoła”'. Jak podkreśla się w wyroku c. Bottone z 15 czerwca 2001 roku, małżeństwo pochodzi od Stwórcy, i od Niego otrzymało cele oraz istotne przymioty, którymi są jedność i nierozerwalność ${ }^{2}$. Wyrażając zgodę małżeńską, która stanowi akt woli (kan. $1057 \$ 2$ KPK) i jest przyczyną sprawczą małżeństwa, nupturienci zawierają więc związek nierozerwalny. Aby zgoda małżeńska była jednak skuteczna, musi zostać

\footnotetext{
1 Por. Jan PAweŁ II, Adhortacja apostolska „Familiaris consortio”, Częstochowa 1982, n. 20.

2 Por. Dec. C. Bottone z 15.06.2001, RRD 93 (2001), s. 385-386; Zob. także Dec. C. Serrano Ruiz z 3.08.2001, RRD 93 (2001), s. 601.
} 
wyrażona zgodnie z prawem (kan. $1057 \$ 1 \mathrm{KPK}$ ), a wewnętrzna zgoda powinna odpowiadać słowom lub znakom użytym przy zawieraniu małżeństwa, co też domniemywa się (kan. $1101 \$ 1 \mathrm{KPK}$ ).

Mając na uwadze sytuacje, w których może dojść do rozbieżności między użytymi przy zawieraniu małżeństwa słowami lub znakami a wewnętrzną zgodą kontrahenta, ustawodawca stanowi, iż „jeśli jednak jedna ze stron albo obydwie pozytywnym aktem woli wykluczyłaby samo małżeństwo lub jakiś istotny element małżeństwa albo jakiś istotny przymiot, zawiera je nieważnie” (kan. $1101 \$ 2 \mathrm{KPK}$ ). Tego rodzaju wykluczenie stanowi tzw. symulację zgody małżeńskiej: całkowitą (w przypadku wykluczenia samego małżeństwa) lub częściową (w przypadku wykluczenia jakiegoś istotnego elementu małżeństwa lub istotnego przymiotu).

W obrębie symulacji częściowej przedmiotem wykluczenia może być m.in. nierozerwalność małżeństwa, będąca, obok jedności, jego istotnym przymiotem (kan. $1056 \mathrm{KPK}$ ). W dowodzeniu woli symulacyjnej, m.in. w odniesieniu do nierozerwalności małżeństwa, w utrwalonej judykaturze rotalnej przyjmuje się trzy „klasyczne” dowody: wyznanie symulanta: sądowe i pozasądowe (probatio directa), oraz przyczynę symulacji (dalszą i bliższą) i okoliczności: pochodzące z okresu przed zawarciem małżeństwa, towarzyszące zawieraniu go oraz z okresu po zawarciu związku (probatio indirecta) ${ }^{3}$.

Gdy chodzi o przyczynę symulacji (causa simulandi), to w orzecznictwie rotalnym podkreśla się, że określenie jej w każdej sprawie jest czymś niezbędnym, nikt bowiem nie działa bez odpowiedniej po temu przyczyny. Przyczyna symulacji powinna być poważna i proporcjonalna, i powinna różnić się od przyczyny zawarcia małżeństwa (causa contrahendi) i przeważać nad nią ${ }^{4}$. Dowód z przyczyny

3 A. Stankiewicz, De iurisprudentia rotali recentiore circa simulationem totalem et partialem, Monitor Ecclesiasticus 32 (1997), nr 2, s. 222.

4 TАмżE, „Oportet quoque adsit seu praecedat causa simulandi gravis vel quia, si rectus modus agendi hominum ex rationabili causa semper procedit, praevalens voluntas contraria contrahentis a sua determinanta causa simulandi eruenda est; qua deficiente, ne quidem actus positivus voluntatis, quo tantum excludi possunt vel matrimonium vel eiusdem bona, adesse potest ideoque et simulatio: omnes quippe 
symulacji jest w judykaturze rotalnej szczególnie akcentowany, jako „miara symulacji”; niekiedy bywa nawet określany mianem „królowej dowodzenia" (probationum regina) ${ }^{5}$.

Gdy mowa o przyczynie (inaczej motywie) symulacji, to należy przyjąć, że niewątpliwie znaczniejszą rolę odgrywa tutaj przyczyna bliższa (causa proxima), a więc konkretna okoliczność skłaniająca kontrahenta do powzięcia aktu symulacyjnego, subiektywnie poważna i nagląca (np. poważna wątpliwość co do pomyślnego losu małżeństwa) ${ }^{6}$. „Niejednokrotnie, czytamy w wyroku c. Funghini z 19 stycznia 2001 roku, w orzecznictwie rotalnym podkreśla się, że bez wskazania pewnej i proporcjonalnej przyczyny, wyraźnie wynikającej z akt sprawy, nie można w sądzie wykazać symulacji, przy czym nie wystarczy istnienie przyczyny dalszej, lecz zawsze należy zwrócić uwagę bardziej na przyczynę bliższą, czyli konkretną, która wystarczy do udowodnienia, a więc racjonalnego przyjęcia domniemanego wykluczenia"?

norunt quantum ex causa simulandi nascatur". Dec. C. Turnaturi z 31.05.2007, RRD 99 (2007), s. 182, n. 12.

5 Por. Dec. C. SCIACCA z 2.03.2001, RRD 93 (2001), s. 206; Zwrot „simulandi causa veluti probationum regina habenda" został przejęty z DEC. C. PARISELla z 14.01.1982, RRD 74 (1982), s. 22.

6 Por. Dec. c. Bottone z 15.06.2001, RRD 93 (2001), s. 387.

7 ,Haud semel animadvertit rotalis iurisprudentia simulationem in iudicio evincere non posse absque certa ac proportionata causa clare ex actis emergente, quin insuper tenet non sufficere existentiam causae remotae sed attendi semper debere potius ad causam proximam seu concretam, quae comprobare valeat vel rationabilem efficere assertam exclusionem”. Dec. C. Funghini z 19.01.2001, RRD 93 (2001), s. 65 , n. 12.; „Nostra iurisprudentia constanter docuit et docet simulationem vinci non posse absque congrua causa clare ex actis emergente, quia homo numquam agit sine apta causa. "Quoad causam simulandi, hoc potissimum animadverti debet: causa, si erit remota seu abstracta a concretis adiunctis, difficilius simulationem ostendit; dum e contra, si sit proxima seu arcte cum hoc detrerminato matrimonio connexa, fere necessario consensum vitiatum probabit» (coram eodem Ponente, sent. diei 3 februarii 1981, RRDec., vol. LXXIII, p. 69, n. 5). Oportet igitur attendi semper potius ad causam proximam seu concretam assertae exclusionis, quam ad causam remotam pro conicienda simulatione”. DEC. C. CIANI z 24.11.2004, RRD 96 
Co się tyczy natomiast przyczyny dalszej symulacji (causa remota), to ma ona charakter bardziej abstrakcyjny, nie mający per se bezpośredniego związku z zawarciem hic et punc małżeństwa; ma jednak wpływ na decyzję nupturienta, usposabiając go do czegoś, w szczególności do zawarcia małżeństwa z jednoczesnym wykluczeniem jakiegoś istotnego elementu lub przymiotu tegoż związku Przyczyna ta pochodzi od osobowości, mentalności, charakteru, obyczajów, wychowania, sposobu postępowania, religijności, kultury, wykonywanego zawodu i doświadczeń życiowych nupturienta ${ }^{9}$. Dla poznania przyczyny dalszej należy dokładnie zapoznać się z biografią domniemanego symulanta, która ujawniłaby jego wychowanie, status społeczny i mentalność sprzyjającą wykluczeniu dobra sakramentu ${ }^{10}$.

Causa remota, jak przyjmuje się w orzeczeniu c. Jaeger z 27 września 2011 roku, nie jest konieczna do tego, by miała miejsce symulacja, jest ona bardziej użyteczna dla uzupełnienia dowodów, choć niekiedy uważana jest za całkowicie konieczną: w szczególnych okolicznościach konkretnego przypadku. „To nie przyczyna dalsza (ani bliższa) stanowi symulację, lecz sama symulacja, w dowodzeniu której causa simulationis zazwyczaj pomaga. Lecz po wystarczającym udowodnieniu in se symulacji z poznanej przyczyny własnej, czyli bliższej, istnienie lub nie jakiejś przyczyny dalszej nie ma już znaczenia, gdyż niczemu już nie służy"11.

(2004), s. 755, n. 9. Por. także Dec. c. Monier z 27.04.2001, RRD 93 (2001), s. 296, n. 6 .

8 Por. Tamże, Dec. c. Pompedda z 13.03.1995, RRD 87 (1995), s. 203.

9 Por. I. ZuAnazzi, La prova della simulazione del matrimonio canonico con particolare riferimento all'esclusione del ,bonum prolis” e del ,bonum coniugum”, w: La prova della nullità matrimoniale secondo la giurisprudenza della Rota Romana, Libreria Editrice Vaticana 2011, s. 319; B. BocCARDELLI, La prova della simulazione del consenso matrimoniale, w: La simulazione del consenso matrimoniale canonico, Libreria Editrice Vaticana 1990, s. 230; Por. także DEC. C. CiAni z 24.11.2004, RRD 96 (2004), s. 754, n. 8; Dec. C. SCIACCA z 1.06.2007, RRD 99 (2007), s. 193, n. 19.

10 Por. Dec. C. Caberletti z 12.01.2006, RRD 98 (2006), s. 17, n. 4.

11 „Praesentia igitur alicuius causae remotae [podkreśl. w tekście - W.G.] minime requiritur ut simulatio habeatur; potius ea invocatur cum ad complendas probationes utitlis vel etiam omnino necessaria, in partucularibus casus conceti adiunctis, 
Jak stwierdza się w wyroku c. Arokiaraj z 12 marca 2012 roku, gdy brak jest całkowicie przyczyny dalszej, cała wiarygodność symulacji opiera się na przyczynie bliższej ${ }^{12}$.

Causa remota symulacji stanowi fundament w ewolucji symulanta, w jego sposobie rozumienia życia, umysłowości oraz ukształtowania woli w stosunku do samego przedmiotu, który chce wykluczyć, a więc - w interesującym nas przypadku - nierozerwalności węzła małżeńskiego ${ }^{13}$.

Przedmiotem podjętego studium jest przyczyna dalsza symulacji zgody małżeńskiej w postaci wykluczenia nierozerwalności małżeństwa w świetle opublikowanych wyroków Roty Rzymskiej pochodzących z lat 2000-2012.

Analiza odnośnych orzeczeń pozwala wyodrębnić trzy podstawowe czynniki stanowiące causa remota wykluczenia nierozerwalności: mentalność prorozwodowa, brak formacji religijnej, osobowość kontrahenta.

\section{Mentalność prorozwodowa}

W epoce współczesnej instytucja rozwodu, znana w ustawodawstwach państwowych, znacząco się upowszechniła także wśród katolików. Nic też dziwnego, że w Konstytucji Gaudium et spes ojcowie Soboru Watykańskiego II wyrazili ubolewanie, iż godność małżeństwa doznaje „przyćmienia” m.in. poprzez „plagę rozwodów” ${ }^{14}$. Tego rodzaju zjawisko deprecjonujące nierozerwalność małżeństwa niewątpliwie nie pozostaje bez wpływu na szerzenie się mentalności

censeatur. Non est causa remota (nec proxima), quae simulationem constutuit; sed ipsa simulatio, quam plerumque vere adfuisse emonstrare iuvat. Sed simulatione in se sufficienter demonstrata, causa insuper propria seu proxima nota, eistentia vel minus alicuius causae remotae momentuum iam non habet cum ad rem non sit". Dec. C. JAeger z 27.09.2011, RRD 103 (2011), s. 380, n. 12.

12 Dec. C. Arokiaraj z 12.03.2012, RRD 104 (2012), s. 55, n. 12.

13 Por. Dec. C. Vaccarotto z 14.06.2012, RRD 104 (2012), s. 193, n. 13.

14 Konstytucja duszpasterska „Gaudium et spes”, w: Sobór Watykański II. Konstytucje, Dekrety, Deklaracje. Tekst polski, Pallotinum 1967, n. 47. 
sprzyjającej wykluczaniu nierozerwalności węzła małżeńskiego. Jakkolwiek mentalność prorozwodowa niekoniecznie musi wskazywać na wykluczanie nierozerwalności małżeństwa (gdy pozostaje jedynie w sferze intelektu), to jednak nierzadko sprawia, iż kontrahenci aplikują swoje przekonania do własnego małżeństwa, podejmując pozytywny akt symulacji ${ }^{15}$.

Generalne stwierdzenie, iż mentalność prorozwodowa może stanowić przyczynę dalszą wykluczenia nierozerwalności, zawarte jest w wyroku c. Bottone z 8 czerwca 2000 roku: „Mentalność ta [prorozwodowa - W.G.], w opisany wyżej sposób, ukształtowana przez strony, staje się odpowiednią przyczyną dalszą ich symulacji ${ }^{16}$. Ów opis mentalności dokonany przez powoda ma następujące brzmienie: „Choć wzrastałem w rodzinie zdrowej i zjednoczonej, byłem już zwolennikiem rozwodu. Miałem wielu przyjaciół mających rodziców żyjących w niezgodzie, i to dało mi do myślenia, że pozostawanie w więzi dwóch osób, które się nie rozumieją i nie kochają się, jest absurdem"17.

„Przyczyna dalsza symulacji, czytamy w wyroku c. Monier z 8 listopada 2002 roku, tkwi w specjalnej mentalności stron, które sprzyjają «mentalności rozwodowej», co dostrzega się jako nic szczególnego w kontekście okoliczności i idei sprzyjających rozwodowi u ludzi młodych, a także mając na uwadze współczesne obyczaje"18.

15 Por. M. Mingardi, Mentalità divorzistica ed esclusione dell'indissolubilità, w: H. Franceschi, M.A. Ortiz (red.), Ius et matrimonium. Temi di diritto matrimoniale e processuale canonico, Roma 2015, s. 163-165.

16 „Mentalista haec, modo supra descripto a partibus sibi efformata, apta causa ramota evadit earundem simulationis”. Dec. c. Bottone z 8.06.2000, RRD 92 (2000), s. 456, n. 9.

17 „Pur essendo io cresciuto in una famiglia sana ed unita, io ero già allora favorevole al divorzio. Avevo molti amici con i genitori discordi e questo mi rendeva pensoso che voler tenere legate due persone che non s'intendono e non si amano è un assurdo”. TAMżE.

18 „Causa simulationis remota invenitur in peculiari mentalitate partium qui fovent «mentalitå divorzista», id quod non insolitum videtur attentis circumstantiis et ideis divortio faventibus inter iuvenes, attentis moribus hodierni temporis". DEc. C. Monier z 8.11.2002, RRD 94 (2002), s. 623, n. 12. Warto przytoczyć w tym miejscu 
W wielu orzeczeniach, m.in. c. Civili z 14 grudnia 2000 roku, można spotkać następujące stwierdzenie: „Przyczyna dalsza symulacji tkwi w umysłowości powoda, który w okresie zawierania małżeństwa nie był zbytnio religijny, łatwo dopuszczając relacje intymne i rozwód"19. W wyroku c. Stankiewicz z 22 stycznia 2004 roku wymieniony ponens przyjmuje wprost, że „przyczyną dalszą wykluczenia przez powoda nierozerwalności małżeństwa była jego gotowość do skorzystania z rozwodu w sytuacji, w której zabrakłoby miłości lub narastałyby trudności w życiu małżeńskim" ${ }^{20}$. Podobnie w orzeczeniu c. Sable z 3 maja 2007 roku stwierdza się, że przyczyną dalszą wykluczenia nierozerwalności małżeństwa jest rodzaj umysłowości, która teoretycznie uznaje wartość rozwodu ${ }^{21}$.

Za szczególnie osobliwy można uznać przypadek rozstrzygnięty orzeczeniem (pozytywnym) c. Sciacca z 1 czerwca 2007 roku dotyczący mężczyzny (praktykującego katolika), który - jak sam zeznał z trudnością przyjmował nauczanie Kościoła, m.in. w przedmiocie nierozerwalności małżeństwa, stając się zdecydowanym rzecznikiem

następujący fragment zeznania powoda: „Sia io che Domitilla [convenuta - W.G.] all'epoca avevamo mentalità divorziata [...] Non condividevo la dottrina della Chiesa circa l'indissolubilità del vincolo. Domitilla non era per niente pratticante della fede cristiana [...] Sia io che Domitilla, non frequentando molto la Chiesa avevamo una mentalità divorzista e non credevamo nel matrimonio sacramento e di questo ne parlavamo anche con amici e parenti apertamente". TAMŻE.

19 "Causa vero simulandi ramota invenitur in forma mentis Actoris, qui tempore nuptiarum religionis studiosus non fuit, facile relationes intimas et divortium admisit". Dec. C. Civili z 14.12.2000, RRD 92 (2000), s. 720, n. 15. Zob. także Dec. c. Sciacca z 2.03.2001, RRD 93 (2001), s. 209, n. 20; Dec. c. Stankiewicz z 14.12.2001, RRD 93 (2001), s. 811, n. 57.

20 „His perpensis, reiectae ab Actore perpetuitatis causa ramota collocari potest in eius propensione ad usum divortii in casu deficientis amoris vel ingravescentis difficulytatis vitae coniugalis". DeC. C. STANKIEwICz z 22.01.2004, RRD 96 (2004), s. 63 , n. 26. Takie nastawienie wynikało zarówno z charakteru owego mężczyzny, jak i z doświadczeń miłosnych. Sam bowiem wyznał sędziemu, że był niespokojny w poszukiwaniu wciąż czegoś nowego, pragnął nowych doświadczeń, a jego wybory życiowe przybierały różne kierunki: od fizyki do medycyny, psychoterapii i polityki. TAMŻE.

${ }^{21}$ Dec. c. Sable z 3.05.2007, RRD 99 (2007), s. 158, n. 18. 
rozwodu ${ }^{22}$. W wyroku tym podkreślono, że „wychowanie katolickie powoda bynajmniej nie świadczy o ważności węzła małżeńskiego, a nawet szkodzi, wyklucza bowiem zwykły błąd (por. kan. 1099 KPK) pozostający w obszarze intelektu, i prawnie nie ma znaczenia"23.

Podobnie było w sprawie rozstrzygniętej wyrokiem c. Defilippi z 5 grudnia 2012 roku, w której powód otrzymał wychowanie chrześcijańskie, które jednak nie wpłynęło na jego życie. Nie stosował się bowiem do nauki Kościoła, w szczególności gdy chodzi o małżeństwo, żyjąc przez wiele lat - na sposób małżeński - z pozwaną zanim zdecydował się zawrzeć z nią małżeństwo. W swojej umysłowości uznawał, że „istotę” tego związku już wypełnił żyjąc w taki sposób, a rozwód traktował jako remedium dla małżeństw, którym się nie powiodło, $\mathrm{w}$ takiej bowiem sytuacji trwanie małżeństwa nie miałoby sensu ${ }^{24}$.

Ów powtarzający się brak spójności między wychowaniem katolickim a poglądami przeciwnymi nierozerwalności małżeństwa trafnie określono w wyroku c. Monier z 18 lutego 2001 roku: „Ten, kto zawarł jedno, a potem drugie małżeństwo, otrzymując lub nie rozwód, albo pojął kobietę już zamężną i rozwiedzioną, choć w dzieciństwie

${ }^{22}$ W okresie przystąpienia przez mężczyznę (powoda w sprawie) do małżeństwa kanonicznego w 1978 roku zawieranie takiego właśnie związku było czymś normalnym. Nie oznaczało to, że akceptując takie małżeństwo powód rezygnował ze swoich idei przeciwnych nierozerwalności. Jako ówczesny sekretarz gminny był zaangażowany w sprawę podtrzymania prawa o rozwodzie (ustawa uchwalona przez Parlament włoski 1 grudnia 1970 roku) rozumianego jako wyraz wolności cywilnej, co miało wpływ na sferę religijną. W momencie podjęcia decyzji o zawarciu małżeństwa był świadom stanięcia przed dwoma rzeczywistościami: rozwodem (wprowadzonym przez prawo), który całkowicie popierał, i nierozerwalnością, głoszoną przez Kościół. Wciąż jednak żywił zastrzeżenia w stosunku do nierozerwalności małżeństwa. Gdy w dniach 12-13 maja 1974 roku odbywało się referendum w sprawie uchylenia ustawy rozwodowej, opowiadał się za rozwodem, co więcej: uprawiał propagandę na rzecz utrzymania tej instytucji. Dec. C. ScIACCA z 1.06.2007, RRD 99 (2007), s. 195-196, n. 24.

23 „Educatio catholica Actoris, quin prosit validitati vinculi, potius nocet, utpote quae exludat merum errorem qui in provincia intellectus manet atque iuridice non relevat”. TAмżE, s. 196, n. 25.

${ }^{24}$ Dec. C. Defilippi z 5.12.2012, RRD 104 (2012), s. 363-364, n. 10; 
otrzymał wychowanie katolickie, ten okazał się mającym za nic węzeł małżeński i ujawnił wolę zawarcia nie węzła nierozerwalnego, lecz czasowego konkubinatu z postanowieniem rozwiązania go, jeśli zabraknie jedności lub gdy wystygnie miłość"25.

Kwestię wpływu współczesnej mentalności odrzucającej nierozerwalność małżeństwa szerzej poruszono m.in. w orzeczeniu c. Pinto z 11 lipca 2009 roku. Jakkolwiek, zauważa ponens, coraz częściej spotyka się błędne nastawienie przeciwne nierozerwalności małżeństwa, to jednak nie w każdym przypadku można to uznać za causa remota wykluczenia dobra sakramentu (należy to udowodnić). Zwraca też uwagę, że nie tylko mentalność prorozwodowa może taką przyczynę stanowić, lecz również sposób myślenia wielu młodych współczesnych ludzi, którzy wręcz zdecydowanie odrzucają instytucję małżeństwa jako pochodzącą z prawa naturalnego i podniesioną przez Chrystusa do godności sakramentu. Nie bez znaczenia pozostaje tutaj negatywny wpływ niektórych środków społecznego komunikowania, które lansują przykład kogoś, kto zawarł małżeństwo dwa, trzy a nawet cztery razy. Tego rodzaju błąd może stanowić domniemanie o wykluczeniu istotnego przymiotu małżeństwa, m.in. nierozerwalności ${ }^{26}$.

W innym orzeczeniu c. Pinto: z 27 marca 2009 roku aktualny dziekan Roty Rzymskiej podkreśla: „Przyczyna dalsza symulacji wynika z umysłowości sprzyjającej rozwodowi powoda, ujawnionej już przed zawarciem małżeństwa ze zdecydowanym przekonaniem: «Myślałem, że jeśli w małżeństwie układa się źle, to się je rozwiązuje»" ${ }^{27}$.

\footnotetext{
25 „Ita qui unum post aliud matrimonium inivit, obtento vel minus divortio, sed mulierem iam nuptam et divortiatam ducit, quamvis catholicam institutionem ab infantia receperit, iam ostendit se coniugale vinculum flocci facere, et voluntatem manifestant contrahendi non vinculum indissolubile, sed temporaneum contubernium cum deliberata voluntate idem rescindendi si concordia cesset vel amor refrigescat (coram Palestro, sent. diei 5 aprilis 1989, RRDec., vol. LXXXI, p. 238, n. 7)”. Dec. C. Monier z 16.02.2001, RRD 93 (2001), s. 157, n. 5.

26 Dec. C. Pinto z 11.07.2008, RRD 100 (2008), s. 238-239, n. 4.

27 „Causa remota simulandi minet ex mente divortio favente ab Actore iam ante nuptias exculta et quidem eminenti ardore: «Pensavo che se un matrimonio va male lo si scioglie»”. Dec. C. Pinto z 27.03.2009, RRD 101 (2009), s. 41, n. 10.
} 
W wyroku tego samego ponensa, z 22 stycznia $2010 \mathrm{roku}^{28}$, znalazło się stwierdzenie (pochodzące z orzeczenia c. Pompedda z 1 lipca 1969 roku), w myśl którego nierozerwalność można wykluczyć w dwojaki sposób: 1. nupturient, który zna właściwą doktrynę o małżeństwie, zawierając ten związek zastrzega sobie prawo rozwiązania go; 2. nupturient ma własną doktrynę o małżeństwie (brak w niej uznania nierozerwalności) i będąc jej oddany „duszą i ciałem”, chce zawrzeć właśnie takie a nie inne małżeństwo ${ }^{29}$.

\section{Brak formacji religijnej}

W wielu przypadkach przyczyną dalszą wykluczenia nierozerwalności jest brak wystarczającej formacji religijnej, co też bardzo często występuje łącznie z mentalnością prorozwodową.

Jak zauważa E.M. Fiore, b. dziekan Roty Rzymskiej, ,znaczna większość katolików, którzy choć uważają się za praktykujących i nawet przeciwnych rozwodowi, bagatelizując religię utrzymuje, że można zastosować własną religijność i manipulować wiarą, stosownie do rozpowszechnionego laickiego rozumienia kultury, bardziej zdradliwego niż błąd mentalny, gdyż sprzyja rozwodowi, gdy tworzy się, wraz z ambiwalentną postawą takich katolików, kultura praktycznej negacji nierozerwalności" 30 .

Jaskrawym przykładem przyczyny dalszej wykluczenia nierozerwalności małżeństwa spowodowanego odejściem od religii może

\footnotetext{
28 Dec. C. Pinto z 22.01.2010, RRD 102 (2010), s. 22, n. 3.

29 Dec. C. Pompedda z 1.07.1969, SRRD 61 (1969), s. 691, n. 3.

30 „La stragrande maggioranza dei cattolici, i quali, pur dicendosi praticanti e addirittura contrari al divortio, secondo il presupposto della frivolizazzione della fede, ritengono di potersi aggiustare la propria religiosità e di poter manipolare la fede in conformità ad un diffuso sentimento laicista della civiltå più insidioso dell'errore mentale favorevole al divorzio, in quanto si instaura, con il comportamento ambivalente di tali attolici, la cultura della negazione dell'indissolubilità [podkreśl. w tekście - W.G.]". E.M. Fione, Conversazione a Palermo, w: Atti del Tribunale Ecclesiastico Regionale Siculo in occasione dell'inaugurazione dell'anno giudiziario 1991-92, Palermo, 30 gennaio 1992, s. 23 nn.
} 
być postawa powoda opisana w wyroku c. Ferreira Pena z 3 grudnia 2004 roku. Jako causa remota wymienionej formy symulacji, której się dopuścił, mężczyzna wskazał zmianę mentalności, jaka dokonała się, gdy zamieszkał w Rzymie, gdzie spotkał liczne osoby o liberalnych poglądach. Pod ich wpływem zapomniał o dobrych zasadach religijnych wpojonych mu przez rodziców, które wypływały z tradycyjnej kultury, którą żyli ludzie w jego miejscowości pochodzenia. Mimo swojej formacji religijnej przyjął mentalność prorozwodową ${ }^{31}$.

W orzeczeniu c. Monier z 16 lutego 2001 roku turnus expressis verbis uznał, że przyczyną dalszą wykluczenia bonum sacramenti powoda w sprawie był jego całkowity indyferentyzm religijny, który oddalił go od Kościoła, od praktyk religijnych - aż do całkowitego zobojętnienia w stosunku do problematyki religijnej. Oboje nupturienci zdecydowanie hołdowali idei rozwodowej, ponieważ byli przekonani, że jest to jedyne rozwiązanie dla małżeństw, które okazały się nieudanymi. Rozwód stanowił dla nich „zdobycz cywilizacji”. Zdaniem powoda, w sytuacji niemożliwości kontynuowania życia wspólnego ucieknięcie się do rozwodu jest czymś słusznym ${ }^{32}$.

O braku formacji religijnej jako przyczynie dalszej wykluczenia nierozerwalności małżeństwa mówi również powód w sprawie zakończonej wyrokiem c. Huber z 12 lutego 2004 roku. Wymieniony ponens stwierdza bowiem: „O przyczynie dalszej symulacji zeznaje mężczyzna"33. Powiedział on, iż otrzymał wychowanie religijne

31 Dec. C. Ferreira Pena z 3.12.2004, RRD 96 (2004), s. 839, n. 12.

32 "Quoad causam simulandi remotam, exstat viri totalis indifferentia erga "problema religioso». Ipse enim fassus est: «Dopo l'adolescenza progressivamente mi sono distaccato dalla Chiesa e da ogni pratica religiosa fino a raggiungere una totale indifferenza nei confronti del problema religioso». In eodem vadimonio vir sustinet ambos studuisse institutioni divortii quia «convinti che fosse l'unica soluzione per i matrimoni che fossero falliti», ac denuo in alio vadimonio ipse confirmavit: «Fermo restando che sull'istituto del divorzio avevamo una comune identità di vedute. D'altra parte per noi era una conquista di civiltà [...] Verificata l'inutilità di continuare una convivenza, ritenevo giusto il ricorso al divorzio»". DEC. C. Monier z 16.02.2001, RRD 93 (2001), s. 158-159, n. 8.

33 „De causa simulandi ramota vir fatetur”. DEC. C. HUBER z 12.02.2004, RRD 96 (2004), s. 123, n. 13. 
w oratorium salezjańskim (w Algerii) do ukończenia dziesięciu lat, lecz później przestał chodzić do kościoła, a jego matka nie miała możliwości kontynuowania tego, co otrzymał wcześniej. Zrywając z Kościołem, powoli stał się materialistą i nie widział celu życia ${ }^{34}$.

Brak wystarczającej formacji religijnej uznano wyraźnie za przyczynę dalszą wykluczenia nierozerwalności małżeństwa w orzeczeniu c. Defilippi z 2 grudnia 2004 roku. Przyjęto tu mianowicie, że powód otrzymał we wczesnym okresie życia od rodziców wychowanie odpowiadające zasadom Kościoła katolickiego, de facto jednak była to formacja niewystarczająca, gdyż słabo uczestniczył w kulcie Kościoła i nie miał zakorzenionych w sobie zasad doktryny i etyki katolickiej, przede wszystkim w odniesieniu do pojęcia małżeństwa i postępowania w stosunku do kobiet. Przez sędziów został uznany jako obojętny w stosunku do owych zasad, a cechował go, jak sam wyznał, styl życia „lekkiego”, swobodnego, liberalnego i „rozrywkowego”, co też potwierdzili świadkowie. „Biorąc pod uwagę, pod każdym względem, stwierdzono w wyroku, całkowitą «lekkość» mężczyzny, o czym wystarczająco zeznali świadkowie, nie był on zatroskany o zbudowanie określonego pojęcia o małżeństwie i jego nierozerwalności według doktryny Kościoła katolickiego" ${ }^{35}$. Sam zresztą ujawnił sędziemu, że gdy chodzi o rozwód, to sprzyjał mu w tym znaczeniu, że dla niego nie było czymś słusznym, gdy dwie osoby, które nie doszły do porozumienia, musiałyby być razem ${ }^{36}$. Jeszcze dobitniej wyraził to w innym zeznaniu ${ }^{37}$.

34 Por. TAmżE. Wprawdzie wyrok w sprawie zapadł negatywny (kilku świadków twierdziło, że powód akceptował koncepcję małżeństwa chrześcijańskiego), niemniej jednak znaczące jest uznanie braku formacji religijnej za potencjalną causa remota symulacji.

35 „Ideo, attenta omnimoda levitate, qua vir tunc se gerebat et de qua satis constat ex vadimoniis testium, ipse sollicitus non erat de exstruenda sua definita notione de matrimonio et de eius indissolubilitayte iuxta Ecclesiae Catholicae doctrinam". Dec. C. Defilippi z 2.12.2004, RRD 96 (2004), s. 813, n. 11.

36 Por. TAmżE, s. 813-814, n. 11.

37 Por. TAMżE. 
Uznanie expressis verbis braku formacji religijnej za causa remota wykluczenia nierozerwalności zostało wyrażone orzeczeniu c. Defilippi z 23 października 2008 roku $^{38}$.

W sprawie rozpoznanej przez turnus c. Caberletti i zakończonej wyrokiem pozytywnym z 4 grudnia 2009 roku, jako przyczynę dalszą symulacji pozwanej w odniesieniu do przymiotu nierozerwalności małżeństwa uznano jej deficyt formacji religijnej w Kościele katolickim. Kobieta ta, która otrzymała formację religijną we wspólnocie protestanckiej, pozbawiona nauki religii w szkole, hołdująca laickiej wizji małżeństwa, niepodzielająca nauki Kościoła katolickiego w tym względzie, o poglądach liberalnych, uważała, że jeśli życie małżeńskie staje się nie do zniesienia, czymś właściwym jest uzyskanie rozwodu ${ }^{39}$.

Znamienny jest również wyrok c. Turnaturi z 14 maja 2009 roku, w którym przyjęto, że formacja materialistyczna (marksistowska), w której małżeństwo traktowane jest jako instytucja czysto moralna, nie zaś religijna, z natury swojej czasowa, pozbawiona nierozerwalności, kształtując poglądy i wolę nupturienta, stanowi przyczynę dalszą wykluczenia przezeń nierozerwalności małżeństwa. Tak było w przypadku mężczyzny, który otrzymał wprawdzie wychowanie chrześcijańskie, lecz z czasem (w latach osiemdziesiątych, jako student) stał się aktywny politycznie (sprzyjając ideom lewicowym); był też przeciwny doktrynie Kościoła i instytucjom kościelnym, opowiedział się za rozwodem we Włoszech, a małżeństwo kościelne zawarł jedynie $\mathrm{z}$ uwagi na narzeczoną ${ }^{40}$.

Brak wiary w odniesieniu do małżeństwa jako sakramentu oraz nieuznawanie żadnego waloru małżeństwa religijnego zostały uznane za przyczynę dalszą wykluczenia nierozerwalności małżeństwa w wyroku c. Alwan z 28 czerwca 2011 roku. W swoim wiarygodnym zeznaniu powód ujawnił, iż w okresie zawierania związku był daleko od Kościoła, a w jego mniemaniu zawarcie małżeństwa kościelnego nie

\footnotetext{
38 Por. Dec. C. DEFILIPPI z 23.10.2008, RRD 100 (2008), s. 279, n. 11.

39 Por. Dec. c. CABRLETTI z 3.12.2009, RRD 101 (2009), s. 333-334, n. 10. Zob. także Dec. C. Serrano Ruiz z 3.08.2001, RRD 93 (2001), s. 605, n. 13.

40 Por. Dec. c. Turnaturi z 14.05.2009, RRD 101 (2009), s. 102-106, n. 21-28.
} 
różniło się od zwyczajnego życia wspólnego, o czym mówił zarówno do narzeczonej, jak i do swoich przyjaciół. Dodał, iż małżeństwo, które zawierał z pozwaną, nie było „definitywne”, uznawał bowiem rozwód ${ }^{41}$.

„Przyczyną dalszą symulacji, czytamy w wyroku c. Monier z 15 grudnia 2011 roku, była umysłowość mężczyzny, obca zasadom Kościoła, również w przedmiocie małżeństwa"42.

Warto nadmienić, że sędziowie rotalni niekiedy wprost stwierdzają, iż przyczyna dalsza wykluczenia nierozerwalności małżeństwa tkwi przede wszystkim w odrzuceniu katolickiej nauki o małżeństwie ${ }^{43}$.

\section{Osobowość kontrahenta}

Przyczyną dalszą wykluczenia bonum sacramenti może być również osobowość zawierającego małżeństwo.

W wyroku c. Turnaturi z 10 kwietnia 2003 roku stwierdzono wprost: „Przyczyna dalsza symulacji tkwi w osobowości mężczyzny”44. Osobowość ta została następująco określona przez świadków: „Rosalino ma charakter autorytarny, dba o poczucie honoru mężczyzny”; „prezentuje również pewien niepokonalny upór, zawsze zmierza do zrobienia tego, co mu się podoba”; „typ uparty, tak że kiedy «włoży» sobie coś do głowy, to nikt nie może go od tego odwieść”; „osoba

41 Por. Dec. C. Alwan z 28.06.2011, RRD 103 (2011), s. 337, n. 21.

42 „Causa simulandi remota reponitur in viri mente aliena a principiis Ecclesiae etiam in povincia matrimonii”. DeC. C. Monier z 15.12.2011, RRD 103 (2011), s. 475, n. 12 .

43 „Aliquid adhuc dicendum manet de causa simulandi prout in doctrina et iurisprudentia, praesertim N.A.F., de more tractatur, et quidem de usitata distinctione causam simulandi remotam inter et proximam. Facile intellegitur ordinaria utilitas discernendi et causa quandam simulationis remotam, quae praesertim in reiectione catholicae de matrimonio doctrinae resideret”. DEC. C. JAEGER z 27.09.2011, RRD 103 (2011), s. 379, n. 12,

44 „Causa simulationis remota in viri personalitate invenitur [...]”. DEC. C. TuRNATURI z 10.04.2003, RRD 95 (2003), s. 208, n. 31. 
anachroniczna na nasze czasy"45. Jak się okazało, owa osobowość powoda oraz jego koncepcja małżeństwa, jako związku, w którym zdecydowanie dominuje mężczyzna, a kobieta nie może być mu równa w podejmowaniu fundamentalnych decyzji życiowych, a także trudne relacje narzeczeńskie stron skłoniły Rosalino do hipotetycznego wykluczenia nierozerwalności małżeństwa ${ }^{46}$.

Różnica charakterów stron została uznana za causa remota wykluczenia nierozerwalności małżeństwa w orzeczeniu c. Monier z 27 czerwca 2003 roku. W bardzo długim okresie (siedmiu lat) przed zawarciem małżeństwa między stronami powstawały coraz to nowe poważne spory i nieporozumienia spowodowane władczym charakterem mężczyzny, który wykluczył wymieniony istotny przymiot małżeństwa ${ }^{47}$.

Również władczy charakter, tym razem kobiety, stał się przyczyną dalszą wykluczenia indissolubilitas matrimonii przez powoda w sprawie zakończonej wyrokiem c. Ciani z 14 lipca 2004 roku $^{48}$.

Niedojrzała, powierzchowna i niestała w relacjach uczuciowych osobowość powoda okazała się przyczyną dalszą wykluczenia dobra sakramentu przez powoda, jak to wykazano w orzeczeniu c. Heredia Estaban z 30 października 2012 roku $^{49}$.

Turnus rotalny c. Monier przyją - w wyroku z 23 listopada 2012 roku - za udowodnioną tezę powoda o wykluczeniu przez niego nierozerwalności małżeństwa, a jako causa remota aktu symulacyjnego wskazał przede wszystkim ,ewolucję uczuciową powoda, która w sposób właściwy nie dokonała się z powodu rozwodu rodziców i nieobecności matki. Okoliczność ta spowodowała, że mężczyzna nie mógł osiągnąć stałości afektywnej, a brak równowagi ducha wyraził

\footnotetext{
45 „Rosalino ha un indole autoritaria e ci tiene al senso dell'onore dell'umo”; „,che presenta pure una certa sua invincibile testardaggine, portato sempre a fare come gli pare”; ,tipo cocciuto che quando si mette una cosa in testa nessuno gliela può togliere”; ,persona anacronistica ai nostri tempi”. ТАмżE.

46 Por. TAmże, s. 202-211, n. 19-39.

47 Por. Dec. C. Monier z 27.06.2003, RRD 95 (2003), s. 439-447, n. 1-16.

48 Por. Dec. C. Ciani z 14.07.2004, RRD 96 (2004), s. 497, n. 13.

49 Por. Dec. c. Heredia Estaban z 30.10.2012, RRD 94 (2012), s. 329, n. 13.
} 
się w jego zazdrości i skłonności do podporządkowania sobie kobiety z powodu obawy o jej utratę; o bardzo trudnym dzieciństwie powoda wypowiedziały się w sądzie obydwie strony i niemal wszyscy świadkowie" ${ }^{50}$. O ułomnościach charakteru mężczyzny, skłonnego do zazdrości i posesywności zeznał nie tylko on sam, lecz także niektórzy świadkowie, a nawet sama pozwana.

Poza tym Trybunał dopatrzył się przyczyny dalszej symulacji w długotrwałym zaniedbaniu przez powoda praktyk religijnych oraz w mentalności prorozwodowej ${ }^{51}$.

Osobowość mężczyzny, nacechowana zamknięciem się w sobie, drobiazgowością, pedanterią, precyzyjnością i niewielkim zainteresowaniem oraz pewną rezerwą w stosunku do innych, a także koncepcja życia w małżeństwie w poczuciu wolności i gotowości do „odzyskania” własnej drogi w każdym momencie, zostały uznane za causa remota wykluczenia nierozerwalności przez mężczyznę w wyroku c. Vaccarotto z 14 czerwca 2012 roku $^{52}$. Ów pozwany już w młodym wieku porzucił praktyki religijne, był zdecydowanym zwolennikiem rozwodu, pragnął zawrzeć małżeństwo jedynie cywilne i niechętnie przychylił się do prośby narzeczonej o zawarcie związku kanonicznego ${ }^{53}$.

W orzeczeniu c. Caberletti z 10 kwietnia 2003 roku jako przyczynę dalszą symulacji zgody małżeńskiej w stosunku do nierozerwalności

\footnotetext{
50 „Causa remota simulandi praeprimis inspicitur in evolutione affectiva Marcelli, quae apta cum tranquillitate progressa non est parentum divortii causa atque ob matris absentiam. In huiusmodi gravi adiuncto Actor firmitatem afectivam consequi non valuit, et signum defectus animi moderationis patefit in Actoris zelotypia necnon in eiusdem proclivitate ad mulierem sub suo dominio servandi, ob metum eandem amittendi; et de Actoris valde difficili infantia utraque pars et fere unusquisque testis locuti sunt”. Dec. C. Monier z 23.11.2012, RRD 104 (2012), s. 348 , n. 10 .

51 „Quoad causam remotam sunulationis, eam invenimus quoque in viri actoris diutina neglegentia quoad praxim christianam necnon in eiusdem mente divortio favente". TAMŻE.

52 Por. Dec. C. Vaccarotto z 14.06.2012, RRD 104 (2012), s. 193-194, n. 13.

53 Por. TAmŻE, s. 195, n. 14.
} 
małżeństwa wskazano mentalność kobiety postrzegającej małżeństwo w kategoriach ekonomicznych (jako „spółka” pracy) ${ }^{54}$.

\section{Zakończenie}

Bonum sacramenti, a więc nierozerwalność małżeństwa, mająca swój fundament w naturze tego związku, jednocząc małżonków na całe życie, nabiera szczególnej mocy w małżeństwie sakramentalnym (kan. $1056 \mathrm{KPK})^{55}$. Nierozerwalność węzła małżeńskiego przynależy do małżeństwa chrześcijańskiego nie tylko in suis principiis, jak pozostałe dobra małżeństwa (jedności i potomstwa), lecz również secundum se, stąd małżeństwo nigdy nie może istnieć bez nierozerwalności (może istnieć bez wierności i potomstwa) ${ }^{56}$, ponieważ istnienie rzeczy (esse rei) nie zależy od korzystania z niej (ab uso suo $)^{57}$.

Jak każda forma symulacji zgody małżeńskiej, tak również wykluczenie nierozerwalności małżeństwa może się dokonać jedynie

54 „Causa remota exclusionis, et quidem hypotheticae, attenta Actricis confessione atque plurium testium depositionibus inspectis, habetur in mulieris cogitatione oeconomica de connubio, quasi in unione coniugali ageretur de foedere laboris". Dec. c. Caberletti z 10.04.2003, RRD 95 (2003), s. 236, n. 12.

55 Między nierozerwalnością i sakramentalnością małżeństwa zachodzi wzajemna relacja konstytutywna, nierozerwalność bowiem ułatwia poznanie sakramentalności, ta zaś stanowi teologicznie ostateczną, chociaż nie jedyną, podstawę nierozerwalności; , Sacramentalitas constituit theologice fundamentum ultimum, etsi non unicum, indissolubilitatis matrimonii". Commissio Theologica InTERnATionalis, Sessio 1977: Propositiones de quaestionibus, Gregorianum 59 (1978), nr 3, s. 459; A. Stankiewicz, De iurisprudentia recentiore circa simulationem totalem et partialem (ed. altera), Romae 1989, s. 32; W. GóRALSKI, Kanoniczna zgoda małżeńska (kanony: 1095-1107), Gdańsk 1991, s. 180-181.

$56 \mathrm{~W}$ odniesieniu do bonum fidei i bonum prolis możliwe jest rozróżnienie między wykluczeniem prawa i wykluczeniem korzystania z prawa.

57 Por. Dec. c. Defilippi z 18.12.1996, RRD 88 (1996), s. 821-822, n. 7. Zob. także A. D'Auria, Il consenso matrimoniale. Dottrina e giurisprudenza canonica. Roma 2007, s. 564-566; P.J. VILADRICH, Konsens małżeński. Sposoby prawnej oceny i interpretacji w kanonicznych procesach o stwierdzenie nieważności mał̇̇enstwa (kanony 1095-1107 Kodeksu Prawa Kanonicznego), tłum. z jęz. hiszpańskiego S. Świaczny, Warszawa 2002, s. 352. 
pozytywnym aktem woli (kan. $1101 \$ 2 \mathrm{KPK}$ ): aktualnym lub wirtualnym i nieodwołanym (nigdy zaś wolą tzw. habitualną lub interpretatywną), powziętym explicite lub implicite, w sposób absolutny lub hipotetyczny (warunkowy) ${ }^{58}$.

W dowodzeniu exclusio boni sacramenti niezwykle ważną rolę odgrywa wskazanie przyczyny (motywu) aktu symulacyjnego, w tym przyczyny dalszej (causa remota). Jakkolwiek ta ostatnia nie pozostaje w bezpośrednim związku z konkretnym małżeństwem, to jednak w pewnym stopniu - wpływa na wolę nupturienta odrzucającego przymiot nierozerwalności.

Gdy chodzi o przyczyny dalsze wykluczenia nierozerwalności małżeństwa, to w najnowszym orzecznictwie rotalnym można dostrzec sytuowanie ich w trzech podstawowych obszarach: mentalności sprzyjającej instytucji rozwodu, braku wystarczającej formacji religijnej oraz szczególnej osobowości kontrahentów. W niejednym przypadku opowiadanie się za rozwodem idzie w parze $\mathrm{z}$ brakiem odpowiedniej formacji religijnej.

W procesie kształtowania się decyzji nupturienta przeciwnej nierozerwalności węzła małżeńskiego niewątpliwie ważniejszą rolę odgrywa causa proxima aktu symulacyjnego.

W pełni uzasadniony wydaje się postulat bacznego zwracania uwagi przez duszpasterzy - podczas kanonicznego badania przedślubnego - na przekonania i poglądy nupturientów w przedmiocie nierozerwalności małżeństwa.

\section{The reason for the further exclusion of the indissolubility of marriage in the light of the contemporary jurisprudence of the Roman Rota} (2000-2012)

\section{Summary}

Indissolubility is an essential attribute of marriage derived from God's law, and the exclusion of indissolubility renders the marriage null and void (can. $1101 \$ 2 \mathrm{CIC}$ ). In proving exclusio boni sacramenti, an extremely

58 Por. Dec. C. Ragni z 4.02.1992, RRD 84 (1992), s. 26. n. 6. 
important role is played by the indication of the cause (motive) of the simulation act, including the further cause (causa remota). Although this reason is not directly related to a particular marriage, it - to some extent - influences the will of the spouse rejecting the attribute of indissolubility. When it comes to the reasons for the further exclusion of the indissolubility of marriage, three basic ones can be discerned in the most recent rotal jurisprudence: a mentality favoring the institution of divorce, the lack of sufficient religious formation and the special personality of contractors.

The postulate of priests, during the canonical pre-wedding examination, to pay close attention to the convictions and views of the spouses regarding the indissolubility of marriage seems fully justified.

Słowa kluczowe: małżeństwo, wykluczenie nierozerwalności małżeństwa, przyczyna dalsza wykluczenia nierozerwalności małżeństwa

Keywords: marriage, exclusion of the indissolubility of marriage, further reason for the exclusion of the indissolubility of marriage

\section{Nota o autorze}

Ks. Wojciech Góralski - profesor zwyczajny prawa kanonicznego, założyciel i pierwszy redaktor naczelny kwartalnika „Ius Matrimoniale”, wiceprzewodniczący Stowarzyszenia Kanonistów Polskich, sędzia w Sądzie Biskupim w Płocku. 